\title{
RURAL TOURISM AND ITS CONTRIBUTION TO THE DEVELOPMENT OF COUNTRYSIDE
}

\author{
L. Dömeová, A. Jindrová
}

Received: December 17, 2010

\begin{abstract}
DÖMEOVÁ, L., JINDROVÁ, A.: Rural tourism and its contribution to the development of countryside. Acta univ. agric. et silvic. Mendel. Brun., 2011, LIX, No. 2, pp. 59-64

The Czech Republic does not have any central registry of rural tourism facilities; there is no information about the availability and quality of services or about their economic results. The goal of this contribution is to describe the current state of rural tourism in the Czech Republic, and to find the bottlenecks, problems and potential risks.

The lack of information about this sector was the motivation for a survey which produced a great deal of information about the situation in the rural tourism business in the Czech Republic. We apply one-dimensional and multiple-dimensional statistical analyses to data from the completed questionnaires. The multiple-dimensional analysis is based on dependency tests and calculations of the intensity of the dependency between variables in contingency tables.

The description and findings arise from the quantification and analysis of the information from the questionnaire survey. We find that most firms in the sector are small (so called micro firms) and usually have no links to the agricultural production. The income from tourism frequently represents only a supplementary part of the businesses' whole revenues and the profitability is to a certain extent dependent on the services offered and how they are promoted. In general, the subjects providing special offers such as horse riding, local foods, firm tourism, etc., are more successful.
\end{abstract}

rural tourism, survey, statistical analysis, countryside

Tourism and related services have a significant importance for development and structural changes of rural regions. More over, tourism as a whole sector forms a substantial part of a national economy. Rural tourism (understood here as all services connected with tourism linked to the countryside localities in which they are provided) fulfils special needs of customers (tourists), brings an economic profit to the providers, and contributes to development of the rural environment and the local communities. Tourist services are source of extra income for local small businesses, and help to maintain the services for the permanent residents over through the year. Small farmers especially appreciate the side income because it enables them to maintain a classical agriculture production without commuting to a second job. Keeping jobs in the countryside is also crucial for maintaining a well-balanced local population.
The structural development of rural areas in the EU is supported by the European Regional Development Fund and the European Social Fund. The specific objectives of this support are (Sharpley, 1997):

1. The development of structurally backward regions.

2. The conversion of regions in industrial decline.

3. The combating of long-term employment.

4. The increase of employment opportunities for young people.

5. a) The adjustment of agricultural structures to accompany the reform of the CAP;

b) The promotion of the development of rural areas.

The Rural Development Plan for the period 20072013 in the Czech Republic mentions the importance of diversification of the agricultural production namely the start of finalizing foods on farms, 
the offer of local goods and providing services like agritourism (Škodová Parmová, Dvořák, 2009).

Statistical sources relating to Czech inward tourism are limited; the official data published by the Czech Statistical Agency (ČSÚ, 2010) do not itemize data according to various types of tourism, e.g., there are no special data files or time rows about rura tourism. The information about rural tourism cannot be extracted from the universal files.

The published researches in this field are often fragmented or empirical (Williams, Baláž, 2002).

The political system and centrally planned economics in the former Czechoslovakia till 1989 inhibited all forms of private businesses, small farms nearly disappeared and only a highly-organised tourism industry existed. In the post 1989 transition period thousands of individuals can become involved in entrepreneurial initiatives ranging from letting spare room to providing conducted tours (Johnson, 1995).

Even though, rural tourism in the Czech Republic have not gain the form and extent typical for neighboring western countries. The traditional relations in countryside were cut and the former diversity (in ownership, in technologies, in products) of agriculture production has not been reached.

There is no clear awareness what the term rural tourism exactly means, which types of services can be included, and if the connection with the agriculture production is crucial.

Labels such as agrotourism, agritourism, farm tourism are often used interchangeably, but have also been used explicitly to denote similar but distinct concepts. The result is a complex and confusing picture (Philip et. al., 2009). It is clear that rural tourism is based on rural amenities; however it is not clear how it relates to agriculture (Fleisher, Tchetchik, 2005).

Sharpley (1997) defines the rural tourism as a form of economic activity which depends upon, and exploits, the countryside. It may be defined both conceptually, as a state of mind, and technically according to activities, destinations and other measurable, tangible characteristics.

The term farm tourism is defined (Nilsson, 2002) as a subset of rural tourism. The rural tourism is based on the rural environment in general whereas the farm tourism is based on the farm and the farmer. The farm tourism can be diversified in to more forms. Phillip et al. (2009) distinguishes:

- Non working farm tourism (ex farm house),

- working farm, passive contact agritourism,

- working farm, indirect contact agritourism,

- working farm, direct contact, staged agritourism,

- working farm, direct contact, authentic agritourism.

In our research, we distinguish only rural tourism with some relations to an agricultural production (accommodation provided by active farmers) and without these relations. We try to compare economic result of both types.
Significant differences between rural accommodation with a working farm and without found Fleitcher and Tchetchik (2005):

1. Experience: farmers had engaged in rural tourism longer than non-farmers, 7.16 compared to 5.65 years.

2. Agritourism: farmers naturally offer more agriculture related activities.

3. Tourism village: more agricultural-based settlements were declared tourism villages and, accordingly, enjoyed governmental support.

4. Attractions: non-farmers have more attractions in the vicinity of their settlements.

5. Labor: farmers invest less working hours than non-farmers.

The situation in the Czech Republic is not the same but similar in some points. We are able use only data from our research because no specific public data are available. As rural tourism we count all tourist services (accommodation, boarding, guided tours, demonstrations, etc.) provided in areas that lie beyond towns and cities.

\section{METHODS AND RESOURCES}

The collection of data was based on the survey which took place in the framework of the project "Definition of suitable areas for development of rural tourism and exploitation of the objects for firm tourism". The project is financed by the Ministry of Local Development of the Czech Republic and realized by the Czech University of Life Sciences in Prague. The responders of the survey are prevailingly operators of accommodation facilities from regions with suitable conditions for tourism. We implemented a pilot investigation first; thereupon we modified the questionnaire so that it better corresponds with the goals of the investigation. Finally, the field investigation took place.

We use basically two methods for distribution of the questionnaires. The first method is based on personal contacts of inquirers and responders in standardized dialogs. The second method is a non-contact collection of data. In this method, the question forms in paper form are distributed. The responder can fill it and send it back (still on the paper) or he/ she can visit the web page of the project www.rozventur.cz, fill the question form and send it by electronic way.

The question form itself has two parts. The first non-public part focuses on the general description of the facility, its legal form and business activities. In this part the responders get a chance to express their meaning on the support provided by the state, region and community.

The second, public, part targets to the exact specification of ach facility. The data from this part will be used consequently in publication on accommodation facilities in the Czech countryside. The publication will be issued as a printed catalogue and as a part of the Internet portal. The questionnaire con- 
tains namely closed questions with several pre-prepared answers. The responder can choose one or more answers.

The analysis of collected data includes one dimensional and multiple dimensional statistics. The one dimensional analysis describes the variables using frequency distribution tables and corresponding graphs. The multiple dimensional analysis searches for the dependencies between variables and it is based on contingency tables (Řezanková, 2007), (Hendl, 2004), (Pecáková, 2004).

For the statistical analyses we use software SPSS, version 17. We fix the significance level for the statistical hypotheses tests to $\alpha=0.05$.

\section{RESULTS}

In the survey we got answers from 286 respondents, owners or operators of rural tourism facilities. After the analysis of missing values we displaced 5 question forms. So, the data matrix for the statistical analyses contained 281 accommodation facilities in rural environment.

The highest number of respondents comes from the Vysočina region; more than $10 \%$ are from the regions Hradec Králové, Plzeň and South Bohemia. The rest of regions were represented by less than $5 \%$ of respondents. It is clear that the selection is not representative nevertheless it is an important sample which can be used for the description of specific features of the rural tourism in the Czech Republic. The most frequent domiciles were places under 500 inhabitants (51.8\%). Majority of respondents considers take their place of living for touristic area.

We find that $61.8 \%$ of the accommodation facilities are in operation all the year round. The remaining ones are opened only in the summer season, in the time of the school holidays - July and August. More than $90 \%$ of accommodation capacities are available in these two months. The customers are mainly the Czech tourists $-92.5 \%$. The foreign visitors use to be in more than $34 \%$ of facilities.

We distinguish only two categories of rural tourism facilities: with some connection with agricultural production and without this connection. The first group covers $27 \%$ of surveyed facilities.

Other factor specific for Czech Republic is the duration of being in the touristic business. The enterprises with both tourism and agriculture are usually longer in business in other countries because they are based on a long tradition of family farms running for generations.

We use the contingency table for the analysis of the dependency of the duration of the tourist business and the existence of an agricultural production. It is visible from the table - see Tab. I - that there are no big differences. The same fact follows also from the chí square test $(p=0.979)$ which do not prove any remarkable difference between the two chosen signs.

The number of accommodation facilities is growing with growing demand for this type of recrea-
I: Contingency table of dependency of duration of business on the type of facility (source: own work)

\begin{tabular}{lccc}
\hline & $\begin{array}{c}\text { Tourism connected } \\
\text { with agriculture } \\
\text { production }\end{array}$ & \\
\hline $\begin{array}{l}\text { How long are you in } \\
\text { the tourism business? }\end{array}$ & Yes & No & Total \\
\hline 0-4 years & 22 & 59 & 81 \\
5-9 years & 18 & 42 & 60 \\
10-14 years & 17 & 43 & 60 \\
$\geq$ 15 years & 15 & 35 & 50 \\
\hline Total & 72 & 179 & 251 \\
\hline
\end{tabular}

tion. More than $49 \%$ of responders declared raising trend in the demand for accommodation. They see the main reason in the improvement of their services and development of public tourist and cycling paths. The marketing of offered services is highly important as well as the general information on the destination. The modern communication channels are the most powerful, especially the Internet.

The most frequent logging places are rooms $62.3 \%$, the second are apartments $-47.0 \%$. The common guest house is only in $8.5 \%$ of objects (see Tab. II). This type of logging is suitable only for a minor part of clients. The tourists are more often interested in privacy and stillness of their own room. The average capacity of the whole object is 23 beds.

II: Types of accommodation offered (source: own work)

\begin{tabular}{lc}
\hline \multicolumn{1}{c}{ Types } & \% \\
\hline Places for tents & 27.8 \\
Places for caravans & 18.9 \\
Common guest house & 8.5 \\
Rooms & 62.3 \\
Apartments & 47.0 \\
\hline
\end{tabular}

Some catering establishment is often included into the accommodation facility. $48 \%$ of investigated objects offer foods. The average capacity is 65 persons. $71.1 \%$ of objects provide full pension, $23.1 \%$ half pension. It follows from the more detailed analysis that the breakfast is served (not in the form of a self service bar) and the lunch and the dinner can be chosen from a menu.

The supplementing services are also offered. The parking places are at $98.5 \%$ of objects; in $89.4 \%$ locked areas are available. The pets are allowed in $77.9 \%$ objects. The foregoing understanding is sometimes necessary and depends on the size and kind of the pet. Anyway this fact shows that the operators have understanding for the demands of the customers and count that the people who seek for spending their holidays in nature are quite often also lovers of animals and usually have their own one.

Only 33.3\% of objects have an access for disabled. It is understandable because old farm buildings, cot- 
tages and bungalows are used. The reconstructions would be expensive and sometimes even impossible. On the other hand the access by disabled should not be under evaluated in the future.

We also investigate the accessibility by public transport, resp. the distance of a bus stop or a railway station from the accommodation facility. The average distance of the bus stop is $0.74 \mathrm{~km}$. The average distance of a railway station is higher $-5.37 \mathrm{~km}$. This is in line with the situation in the whole Czech Republic where the network of bus lines is thicker and the bus stops are nearly in all villages. In addition, more than half of the objects (58.7\%) offer transport of their customers from the stop or station; $40 \%$ take luggage.

\section{DISCUSSION}

We find that there is remarkably higher number of the Czech tourists than foreigners. The situation has changed from the ninetieths when prevailed interest from abroad (Johnson, 1995), (Williams, Baláž, 2002). The higher interest of the Czech tourists in rural tourism can be explained as a result of oversaturation with trips abroad. We observe also some kind of return to nature, to more healthy way of living, preference of home made food in bio quality, if possible. Also the global economic crisis leads to search for less expensive destinations.

The lower number of facilities with direct link to an agricultural production is real and was mention, e.g. in Škodová Parmová, Dvořák, 2009. In many objects which were privatized (in fact returned to its original owners) the agricultural production was not restored and the buildings and other property is used only for living and recreation.

We observe also the occupancy of beds and the economic results of the firms. Better occupancy is reached when the offer of other services is wide. The accommodation standard is good and there are usually other facilities: ski stores, outside swimming pools, children's playgrounds, etc. There are also special offers for families with children.

We see reserves in offer of a firm tourism. It is introduced only in $19.3 \%$ of facilities. The firm tourism has a great potential in improving the occupancy especially in low seasons. However, it is more suitable for bigger objects and often calls for special equipment as the Internet connection and meeting room with communication technique.

The online payments and reservation are not used even though majority of firms have their own web pages and get many customers through these pages and email. In this field we see an occasion for support by the EU, the state or region. Joint web servers with offers from the whole region or republic are useful both for entrepreneurs and customers. The technical and organizational realization is over the capacity of small entrepreneurs.

The fact that the firms with agricultural production are usually longer in the touristic business was not proved (in contradiction to Fleischer, Tchetchik, 2005). It means there are no traditional links between farming and tourism. The rural tourism itself is not stabilized. Its dynamical development with many changes in ownership, services and profitability is a nowadays reality in some places and a future in others.

\section{SUMMARY}

The article brings exact data and analyses of the current state in rural tourism in the Czech Republic. The statistical analyses are based on our own survey made in several regions. There are no official data on different branches of tourism. The operators of the rural tourism services are not obliged to indicate any details of their offers and incomes with exception of the declaration of taxes. Quite often they are involved in more entrepreneurial activities. There is no duty and no tangible motivation to answer the survey and that's why getting the input data is a problem.

We found that the rural tourism in the Czech Republic represents young and very dynamic branch. Majority of investigated object are in business not longer than 9 years. We do not prove any dependencies between the connection with agriculture production and length of being in touristic business (as it is usual in other countries). Only $27 \%$ of objects are in some relation to agriculture. The accommodation capacities are usually small (average 23 beds); occupied mainly by Czech Tourists (92.5\%). The tourist services benefit from the thick network of public transport. $61.8 \%$ of the accommodation facilities are in operation all the year round; the rest only during the summer holidays. Usually there are also some other services offered (food in $47 \%$ of objects) and wider offer of services improves the occupancy of the object. The most important reserves we see in exploitation of modern communication technologies (e.g. the Internet, electronic reservation systems) and centralized promotion and public information sources.

\section{Acknowledgement}

The paper is supported by the grant project of the Ministry of Local Development of Czech Republic No. WD-12-07-2 - Definition of suitable areas for development of rural tourism and exploitation of the objects for firm tourism. 


\section{REFERENCES}

ČSÚ, 2010: Time rows tourism. [cit. 2010-09-13]. Cited from: $h t t p: / / w w w . c z s o . c z / c s u / r e d a k c e . n s f / i / c r u \_c r$.

FLEISCHER, A., TCHETCHIK, A., 2005: Does rural tourism benefit form agriculture? Tourism Management 26, pp. 493-501.

HENDL, J., 2004: Přehled statistických metod zpracování dat. Analýza a metaanalýza dat. Praha. Portál, s. r. o. ISBN 80-7178-820-1.

JOHNSON, M., 1995: Czech and Slovak Tourism, Patterns, problems and prospects. Tourism Management 16, pp. 21-28.

PECÁKOVÁ, I., 2004: Poŕizování a vyhodnocování dat ve výzkumech veŕejného mínèní. Praha: Oeconomica. ISBN 80-245-0753-6.

PHILIP, S. et al., 2009: A typology for defining agritourism. Tourism Management, pp. 1-5, article in press.
ŘEZANKOVÁ, H., 2007: Analýza dat z dotazníkových šetrení. First edition. Praha: Professional Publishing. ISBN 978-80-86946-49-8.

ŠKODOVÁ PARMOVÁ, D., DVOŘÁK, V., 2009: Support of agroturism in the Czech Republic illustrated on the case of South Bohemian Region. Central European Journal of Regional Development and Tourism, Vol. 1, pp. 156-164.

SHARPLEY, R., SHARPLEY, J., 1997: Rural Tourism: An Introduction. First edition. International Thomson Business Press. ISBN 0415140102.

WILLIAMS, A. M., BALÁŽ V., 2002: The Czech and Slovak Republics: conceptual issues in the economic analysis of tourism in transition. Tourism Management 23, pp. 37-45.

\section{Address}

doc. Ing. Ludmila Dömeová, CSc., Ing. Andrea Jindrová, Provozně ekonomická fakulta, Česká zemědělská univerzita v Praze, Kamýcká 129, 16521 Praha, Česká republika, e-mail domeova@pef.czu.cz,jindrova@pef. 
